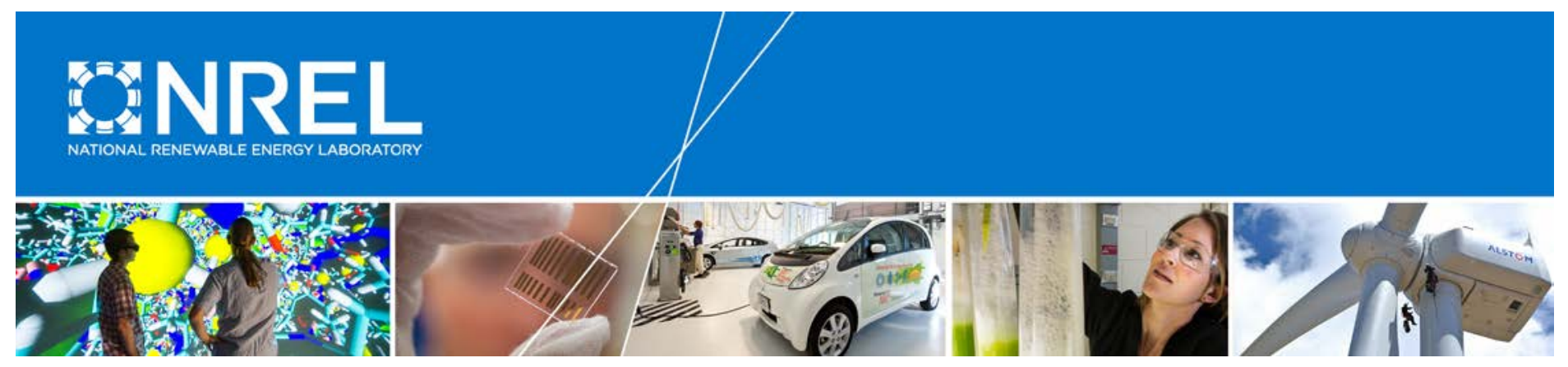

\title{
Colorado State University: A Midscale Market Solar Customer Case Study
}

Alison Holm and Ilya Chernyakhovskiy National Renewable Energy Laboratory

NREL is a national laboratory of the U.S. Department of Energy Office of Energy Efficiency \& Renewable Energy Operated by the Alliance for Sustainable Energy, LLC

This report is available at no cost from the National Renewable Energy Laboratory (NREL) at www.nrel.gov/publications.

Technical Report

NREL/TP-7A40-67540

December 2016 


\title{
Colorado State University: A Midscale Market Solar Customer Case Study
}

\author{
Alison Holm and Ilya Chernyakhovskiy \\ National Renewable Energy Laboratory
}

Prepared under Task No. ST6B.1730

NREL is a national laboratory of the U.S. Department of Energy Office of Energy Efficiency \& Renewable Energy Operated by the Alliance for Sustainable Energy, LLC

This report is available at no cost from the National Renewable Energy Laboratory (NREL) at www.nrel.gov/publications.

National Renewable Energy Laboratory 15013 Denver West Parkway Golden, CO 80401

303-275-3000 • www.nrel.gov

\section{Technical Report}

NREL/TP-7A40-67540

December 2016

Contract No. DE-AC36-08GO28308 


\section{NOTICE}

This report was prepared as an account of work sponsored by an agency of the United States government. Neither the United States government nor any agency thereof, nor any of their employees, makes any warranty, express or implied, or assumes any legal liability or responsibility for the accuracy, completeness, or usefulness of any information, apparatus, product, or process disclosed, or represents that its use would not infringe privately owned rights. Reference herein to any specific commercial product, process, or service by trade name, trademark, manufacturer, or otherwise does not necessarily constitute or imply its endorsement, recommendation, or favoring by the United States government or any agency thereof. The views and opinions of authors expressed herein do not necessarily state or reflect those of the United States government or any agency thereof.

This report is available at no cost from the National Renewable Energy Laboratory (NREL) at www.nrel.gov/publications.

Available electronically at SciTech Connect http:/www.osti.gov/scitech

Available for a processing fee to U.S. Department of Energy and its contractors, in paper, from:

U.S. Department of Energy

Office of Scientific and Technical Information

P.O. Box 62

Oak Ridge, TN 37831-0062

OSTI http://www.osti.gov

Phone: 865.576.8401

Fax: 865.576.5728

Email: reports@osti.gov

Available for sale to the public, in paper, from:

U.S. Department of Commerce

National Technical Information Service

5301 Shawnee Road

Alexandria, VA 22312

NTIS http://www.ntis.gov

Phone: 800.553 .6847 or 703.605 .6000

Fax: 703.605.6900

Email: orders@ntis.gov 


\section{Acknowledgments}

This work was funded by the U.S. Department of Energy's (DOE's) Office of Energy Efficiency and Renewable Energy. The authors thank the Solar Energy Technologies Office for its support of this work. The authors also thank Carol Dollard, Stacey Baumgarn, Jonathan Feiman, Susanne Cordery-Cotter, and Michael Randall of the Colorado State University (CSU) Facilities Management Department for an informative interview that facilitated this case study. Special thanks go to Carol Dollard for organizing a CSU site visit and for providing key information and feedback that made this report possible. For their thoughtful review of this document, the authors thank Jenny Heeter and Eliza Hotchkiss, National Renewable Energy Laboratory; James Critchfield, Environmental Protection Agency Green Power Partnership; and Daniel Boff, DOE SunShot Initiative.

This work was supported by the U.S. Department of Energy under Contract No. DEAC36-08GO28308 with the National Renewable Energy Laboratory. 


\section{Acronyms and Abbreviations}

\section{AASHE}

CSU

DOE

EPA

ESPC

FY

GHG

GW

IOU

$\mathrm{kW}$

MW

NREL

PPA

PV

REC

RPS

SREC

TPO
Association for the Advancement of

Sustainability in Higher Education

Colorado State University

U.S. Department of Energy

U.S. Environmental Protection Agency energy savings performance contract

fiscal year

greenhouse gas

gigawatt

investor-owned utility

kilowatt

megawatt

National Renewable Energy Laboratory

power purchase agreement

photovoltaics

renewable energy credit

renewable portfolio standard

solar renewable energy credit

third-party ownership 


\section{Table of Contents}

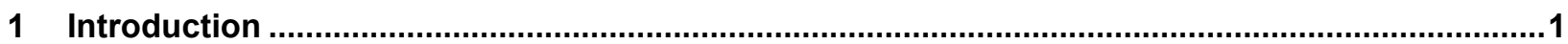

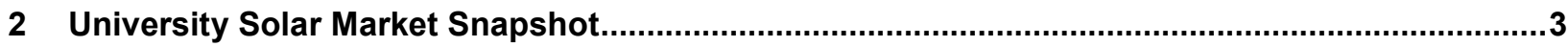

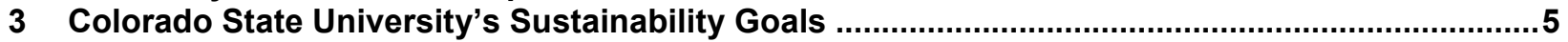

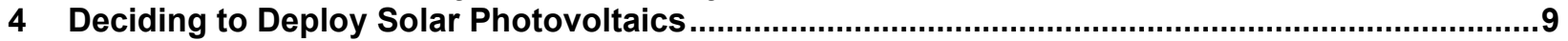

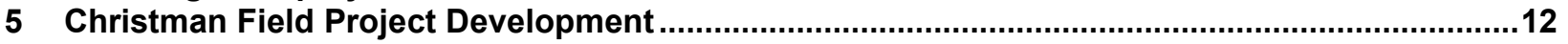

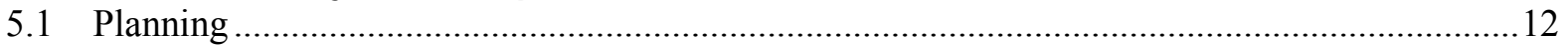

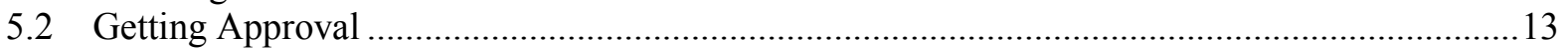

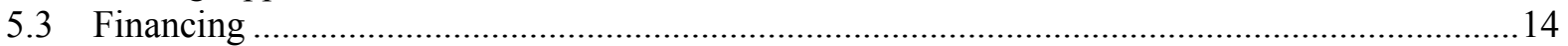

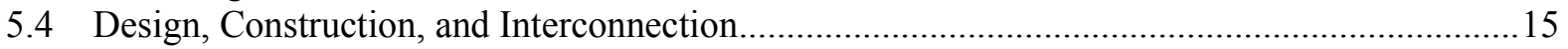

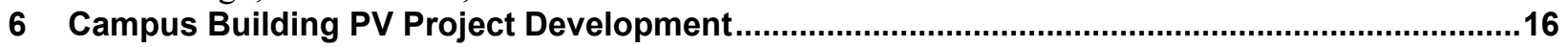

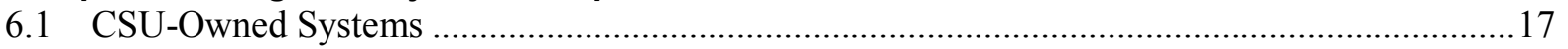

6.2 Roof-Lease PV Systems with Fort Collins Utilities ............................................................ 18

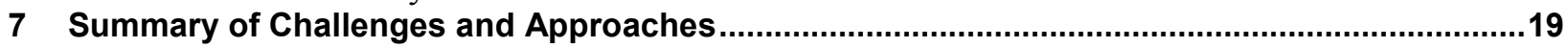

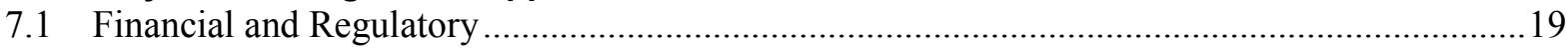

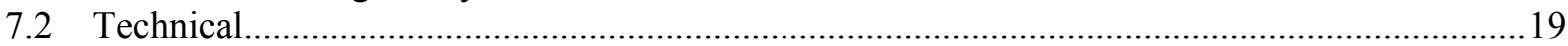

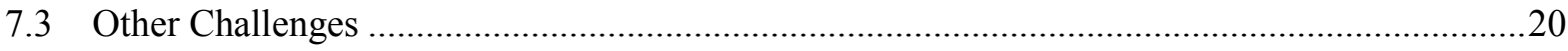

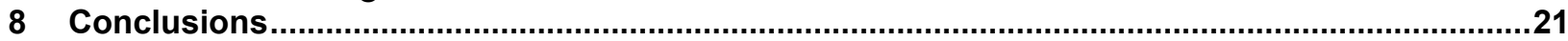

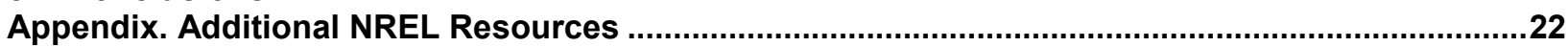

Technical Assistance: Solar Screenings and Implementation Assistance for Universities..................22

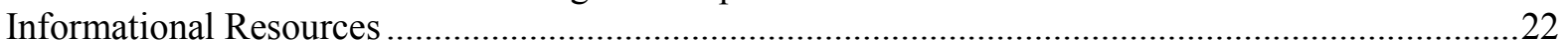

\section{List of Figures}

Figure 1. University solar PV installed capacity additions by year and total capacity online $(\mathrm{kW})$............3

Figure 2. Map of solar installations at CSU ....................................................................................

Figure 3. Rooftop PV system on the Engineering Building at CSU's main campus in Fort Collins .......... 10

Figure 4. 5.3 MW solar PV array at Christman Field on CSU's Foothills Campus..................................13

Figure 5. Rooftop PV on CSU's Student Recreation Center........................................................... 17

Figure 6. Rooftop PV on CSU's University Center for the Arts ............................................................ 18

\section{List of Tables}

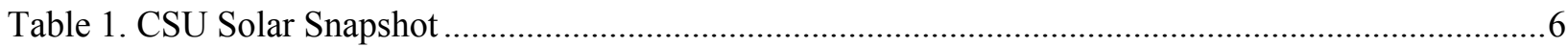

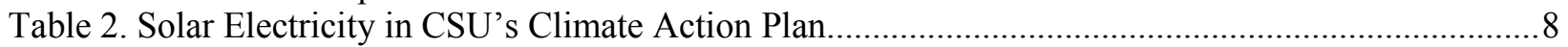

Table 3. Christman Field Solar Development Snapshot................................................................. 12

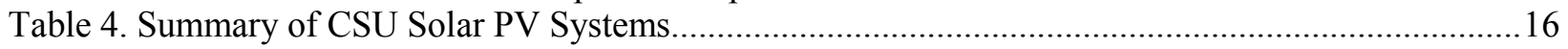




\section{Introduction}

Solar photovoltaic (PV) technology experienced an unprecedented level of investment and deployment between 2005 and 2015. ${ }^{1}$ Driven by rapidly falling module costs, high consumer demand, and targeted state and local incentives, annual solar PV installations have risen from 79 megawatts (MW) in 2005 to $7,260 \mathrm{MW}$ in 2015 , representing more than a $9,000 \%$ increase. $^{2}$ Despite this growth, a large untapped market for solar deployment still exists in midscale market investments. Midscale market projects are loosely defined as solar PV installations ranging from 100 kilowatts (kW) to $2 \mathrm{MW} .{ }^{3}$ The midscale solar PV market more broadly includes behind-themeter systems that are not captured in the residential or utility-scale sectors. ${ }^{4}$ Universities constitute one building sector with large potential for midscale market PV investment. Recent estimates show that if all universities in the United States installed enough PV to meet $25 \%$ of their annual electricity consumption, this would cumulatively result in just over 16 gigawatts (GW) of additional installed PV capacity. ${ }^{5}$ This case study focuses on one university solar customer, Colorado State University (CSU), to provide a detailed example of the challenges, solutions, and opportunities associated with university solar power procurement. ${ }^{6}$

CSU first entered the solar PV market in 2009 with an $18.9 \mathrm{~kW}$ rooftop installation on the Engineering Building at its Fort Collins, Colorado campus. Since then, the school has drastically increased its solar procurement, with a total of $6,754 \mathrm{~kW}$ (roughly $6.7 \mathrm{MW}$ ) of PV installed as of July 2015. Among college campuses in the United States, CSU ranks fifth in terms of total installed PV capacity. ${ }^{7}$ CSU's efforts to integrate solar energy into its campus illustrate some of the key considerations for universities growing their renewable energy portfolios within the context of a continuously evolving solar PV landscape.

This case study highlights CSU's decision-making process, campus engagement strategies, and relationships with state, local, and utility partners, which have culminated in significant oncampus PV deployment. Section 2 provides a brief snapshot of the broader university solar purchasing market; Section 3 describes CSU as an institution and summarizes its PV installations to date; Section 4 discusses the initial decision to deploy PV on campus; and Section 5 describes the various project development and approval processes. Subsequent sections outline in more detail how CSU's various rooftop and ground-mounted PV systems are configured and the challenges and lessons learned from the development processes. The bulk of the information in this report was gathered during an in-person interview in March 2016 with several CSU officials

\footnotetext{
${ }^{1}$ Solar Energy Industries Association, U.S. Solar Market Insight, Q2 2016 (Washington, D.C.: Solar Energy Industries Association, 2016), http://www.seia.org/research-resources/solar-market-insight-report-2016-q2.

${ }^{2}$ Solar Energy Industries Association, U.S. Solar Market Insight, 2015 Q4 (Washington, D.C.: Solar Energy Industries Association, 2016), http://www.seia.org/research-resources/solar-market-insight-2015-q4.

${ }^{3}$ Lori Bird, Pieter Gagnon, and Jenny Heeter, Expanding Midscale Solar: Examining the Economic Potential, Barriers, and Opportunities at Offices, Hotels, Warehouses, and Universities, NREL/TP-6A20-65938 (Golden, CO: National Renewable Energy Laboratory, 2016), http://www.nrel.gov/docs/fy16osti/65938.pdf.

${ }^{4}$ Behind-the-meter systems are designed to produce electricity for on-site use and are located directly on the property where the energy will be consumed without the electricity first being routed through the utility or grid.

${ }_{6}^{5}$ Bird, Gagnon, and Heeter, Expanding Midscale Solar.

${ }^{6} \mathrm{CSU}$ is considered a midscale market solar customer. Not all of CSU's individual solar PV systems fall directly within the $100 \mathrm{~kW}$ to $2 \mathrm{MW}$ range.

7 "Top Ten Campuses by Total Installed Capacity," Association for the Advancement of Sustainability in Higher Education, accessed December 4, 2016, http://www.aashe.org/resources/campus-solar-photovoltaicinstallations/top10/\#top-capacity.
} 
who were instrumental in formulating and executing the university's solar strategy. ${ }^{8}$ The intention of this case study is to highlight the challenges and potential for solar implementation on university campuses in the United States.

\footnotetext{
8 The in-person interview took place at CSU on March 17, 2016. The CSU interviewees were: Carol Dollard, Facilities Engineer; Stacey Baumgarn, Campus Energy Coordinator; Jonathan Feiman, Project Manager; Susanne Cordery-Cotter, Environmental Engineer; and Michael Randall, Maintenance Engineering.
} 


\section{University Solar Market Snapshot}

Based on an analysis of two different data sets, the authors estimate that approximately 306 megawatts (MW) of solar PV capacity have been installed at universities across the United States as of 2015. ${ }^{9}$ Universities have seen a significant rise in installed solar PV since 2003.

To illustrate this trajectory, in 2003, 1,444 kW of PV were installed on college campuses, doubling the total amount of solar PV at universities in a single year. Annual installed capacity totals spiked in 2010 and 2011 with over 40,000 kW installed in each year (see Figure 1). ${ }^{10}$

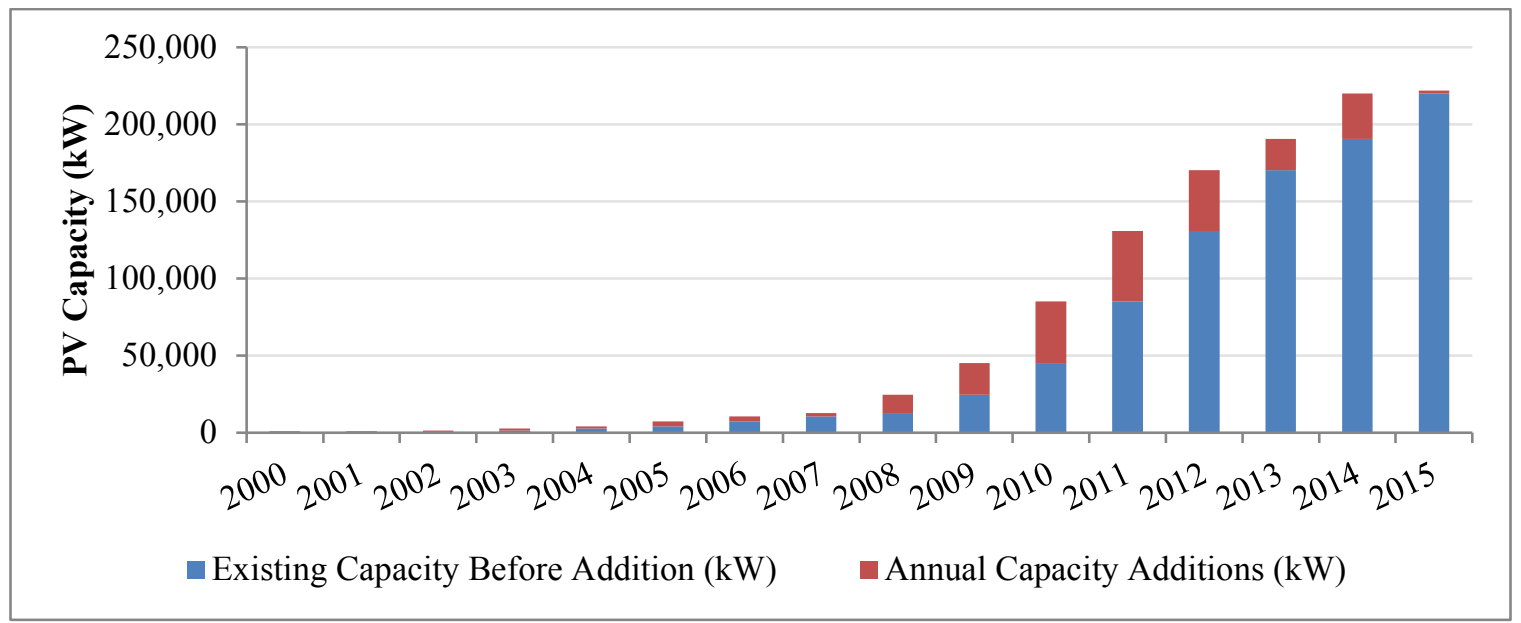

Figure 1. University solar PV installed capacity additions by year and total capacity online (kW) ${ }^{11}$

Note: This is a lower-bound estimate and does not include all solar PV systems installed at universities in the United States. Due to the self-reporting nature of the Association for the Advancement of Sustainability in Higher Education (AASHE) Campus Solar Photovoltaic Installations database, the capacity additions shown here underestimate the total market.

Universities use four primary business models to install on-campus solar energy systems:

- Institution-owned, in which the university owns the PV system outright

- Power purchase agreement (PPA), under which a third-party solar developer installs, operates, maintains and retains ownership of the PV system

- Lease, another form of third-party ownership (TPO) distinguished from a PPA in that the offtaker (defined below) leases the entire system rather than purchasing the power output

\footnotetext{
${ }^{9}$ NREL compiled data from the Association for the Advancement of Sustainability in Higher Education (AASHE) Campus Solar Photovoltaic Installations Database and from the Second Nature Reporting System. The AASHE database is available at www.aashe.org/resources/campus-solar-photovoltaic-installations/. The Second Nature database is available at $\underline{\mathrm{http}: / / \text { reporting.secondnature.org/. }}$

${ }^{10}$ Due to differences in the information reported, these estimates are based only on the AASHE data set, which represents a cumulative installed capacity of $222,253 \mathrm{~kW}$ as of August 2016.

${ }^{11}$ Data source: Association for the Advancement of Sustainability in Higher Education (AASHE) Campus Solar Photovoltaic Installations Database, retrieved July 2016, www.aashe.org/resources/campus-solar-photovoltaicinstallations/.
} 
- Energy savings performance contract (ESPC), in which an energy service company audits the campus for energy savings opportunities in order to implement both energy reduction and renewable energy strategies. ${ }^{12}$

The majority of campus solar PV systems are financed via PPAs. The solar purchaser, or offtaker (in this case the university), buys the electricity at a predetermined rate for the length of the contract term (generally around 20 years). Based on data from AASHE, an estimated $68 \%$ of the solar PV capacity installed at universities was financed through PPAs. ${ }^{13}$ TPO models are popular among universities in part due to U.S. tax incentive structures. Because tax-exempt entities (which include not-for-profit universities) cannot directly monetize tax credits, universities must often partner with TPOs in order to benefit from the cost savings associated with tax credits, which are typically passed down in the form of lower PPA rates or lease costs.

In the university solar PV arena, PPAs have, on average, translated into larger system sizes and higher installed capacity at individual universities. The average size of PPA-financed campus PV systems is $700 \mathrm{~kW}$, compared to an average system size of $100 \mathrm{~kW}$ for non-PPA financed installations. ${ }^{14}$ PPAs facilitate larger systems in part because they do not require capital investment from the university, with the system owner bearing the majority of the financial risk. However, as CSU's solar purchasing experience reveals, institutions may elect to pursue a variety of financing mechanisms for individual solar systems on campus, depending on the specific project and the policy and financing landscape that exists at the time of procurement.

The choice of business model for on-campus solar energy systems also has important implications for a university's sustainability and carbon reduction goals. In the United States, the positive environmental attributes associated with each unit of energy produced by a renewable energy system are known as renewable energy certificates (RECs), or in the case of solar PV in some markets, solar renewable energy certificates (SRECs). RECs represent the environmental benefits of one megawatt-hour (MWh) of generation and can be sold separately or together with the underlying electricity. RECs were developed as states passed renewable portfolio standards (RPSs) and required fuel mix disclosure labels. RECs are also used in the voluntary market, where customers buy renewables to meet sustainability goals. For universities, RECs serve as a primary metric that can substantiate progress toward sustainability, emission reduction, and clean energy goals. Whether a university retains the RECs associated with an on-campus solar energy system depends on the business model used to finance the installation. For example, under a PPA or lease agreement, the third-party system owner may retain all or some of the associated RECs.

In some cases, universities that pursue PPA or lease agreements may need to purchase supplemental RECs from the market to meet near- and long-term campus sustainability goals. This presents a financial trade-off between REC-retaining business models and non-RECretaining options. In other cases, universities with ambitious sustainability goals may buy supplemental RECs in the marketplace while also retaining all RECs associated with on-campus solar energy production.

\footnotetext{
${ }^{12}$ Walter Simpson, "Getting the Most out of an Energy Performance Contract - Part 1," The Association for the Advancement of Sustainability in Higher Education blog, April 7, 2009, http://www.aashe.org/blog/getting-mostout-energy-performance-contract- $\% \mathrm{E} 2 \% 80 \% 93$-part-1.

${ }^{13}$ National Renewable Energy Laboratory, "Using Power Purchase Agreements for Solar Deployment at Universities," NREL/BR-6A20-65567 (Golden, CO: National Renewable Energy Laboratory, 2016), http://www.nrel.gov/docs/gen/fy16/65567.pdf.

${ }^{14}$ Ibid.
} 


\section{Colorado State University's Sustainability Goals}

CSU is a public land-grant university with a flagship campus located in Fort Collins, Colorado. University enrollment was 32,236 students in 2015 and the institution's overall electricity usage was $169,000 \mathrm{MWh}$ for that fiscal year (FY). CSU acknowledges that, as a land-grant university, they are "compelled to steward, conserve, and protect" the environment, making sustainability a central feature of the institution's academics, research programs, operations, and outreach strategies. ${ }^{15}$

Building off of earlier sustainability efforts, CSU released its first Climate Action Plan in 2010, which set the foundation for achieving carbon neutrality by 2050. In the shorter term, CSU intends to reduce GHG emissions by $75 \%$ over 2010 numbers by 2030 . The university's comprehensive GHG emissions reduction plan includes a wide range of energy efficiency, renewable energy, solid waste reduction, and transportation-related strategies. CSU has a longterm (more than 20 years) solar vision that is projected to reduce emissions by $4 \%$ over net FY 2010 emissions levels. CSU also set goals associated with purchasing or producing a portion of the university's electricity consumption from renewable sources and factors state and utility renewable energy policies into its emissions reductions projections. For example, because CSU purchases power from several utilities, utility requirements to integrate renewable energy into their portfolios under Colorado's Renewable Energy Standard will reduce the emissions associated with CSU's electricity purchases. The solar power facilities located across CSU's campuses contribute to these goals in varying capacities depending on the ownership structure and environmental attributes associated with each system. ${ }^{16}$ Table 1 below summarizes key details about CSU and the school's solar development trajectory.

\footnotetext{
15 "State of Sustainability," Colorado State University, accessed September 2016, http://green.colostate.edu/.

${ }^{16}$ Colorado State University, Climate Action Plan (Fort Collins: Colorado State University, 2015), www.fm.colostate.edu/sustain/downloads/CAP_2015_Update.pdf.
} 
Table 1. CSU Solar Snapshot

CSU

Location

- Fort Collins, CO

University size (2015)

- 32,236 enrolled students

- 1,468 academic staff

- 4,379 administrative staff

Annual electricity usage

- $\quad 169,000 \mathrm{MWh}$ (fiscal year 2015)

Average electricity rate

- $\$ 0.07 / k W h$ (fiscal year 2015) ${ }^{17}$

Clean energy target

- Zero net greenhouse gas (GHG) emissions by 2050

Utility suppliers

- Fort Collins Utilities (municipal utility)

- Xcel Energy (investor-owned utility)

\section{Solar PV Summary}

\section{Installed capacity}

- Main Campus: Thirteen solar PV arrays (combination of ground-mount and rooftop systems) throughout campus with an average installed capacity of $112 \mathrm{~kW}$

- Foothills Campus: Two-phase groundmounted solar PV plant with cumulative installed capacity of $5.3 \mathrm{MW}$

- Total installed solar PV capacity at CSU is $6,754 \mathrm{~kW}$ as of July 2015.

Annual electrical output

- $10,430 \mathrm{MWh}$

Total number of PV panels

- $\quad 28,181$

\section{Mounting}

- Ground mount: Combination of single axis tracking (2 MW) and fixed tilt (3.3 MW)

- Rooftop: Some ballasted and some direct mounting.

\section{Solar Development}

\section{Financing mechanisms}

- Campus building systems: Direct ownership (260 kW) and roof lease $(1,194 \mathrm{~kW})$

- Christman Field array: Solar PPA

System ownership

- Campus building systems: CSU (260 kW) and The Atmosphere Conservancy $(1,194 \mathrm{~kW})$

- Christman Field array: SunEdison

\section{REC ownership*}

- Campus building systems: CSU (260 kW) and Fort Collins Utilities $(1,194 \mathrm{~kW})$

- Christman Field array: Xcel Energy (5.3 MW)

*Note: all RECs will eventually be returned to CSU and are calculated into the university's long-term net-zero emissions strategy.
- Misaligned incentives can yield a disconnect between optimal and actual system design, i.e., incentive structure for rooftop systems does not always enable the most cost-effective system sizing and use of roof space

- Importance of working closely with city permitting office to navigate a new project permitting process

- Student perception of "green" campus is critical, but development timeframes do not always align with academic calendar, which can make student involvement in PV procurement difficult

- Steep learning curve in the beginning, but the process allowed CSU to build its institutional capacity, which made subsequent solar development easier to pursue

- CSU benefited from having available, university-owned land and from access to in-house experts during the permitting and development processes.

As of FY 2015, CSU had approximately 6.7 MW of solar PV installed across its campuses, including 13 smaller solar PV systems on buildings across the main campus and a much larger

\footnotetext{
${ }^{17}$ Average electricity rates vary by campus. Main Campus: $\approx \$ 0.067 / \mathrm{kWh}$; Foothills Campus: $\approx \$ 0.08 / \mathrm{kWh}$; rates at smaller campuses range from $\approx \$ 0.08-\$ 0.14 / \mathrm{kWh}$.
} 
(5.3 MW) ground-mounted solar PV array at Christman Field, a retired airstrip on the Foothills Campus (see Figure 2).

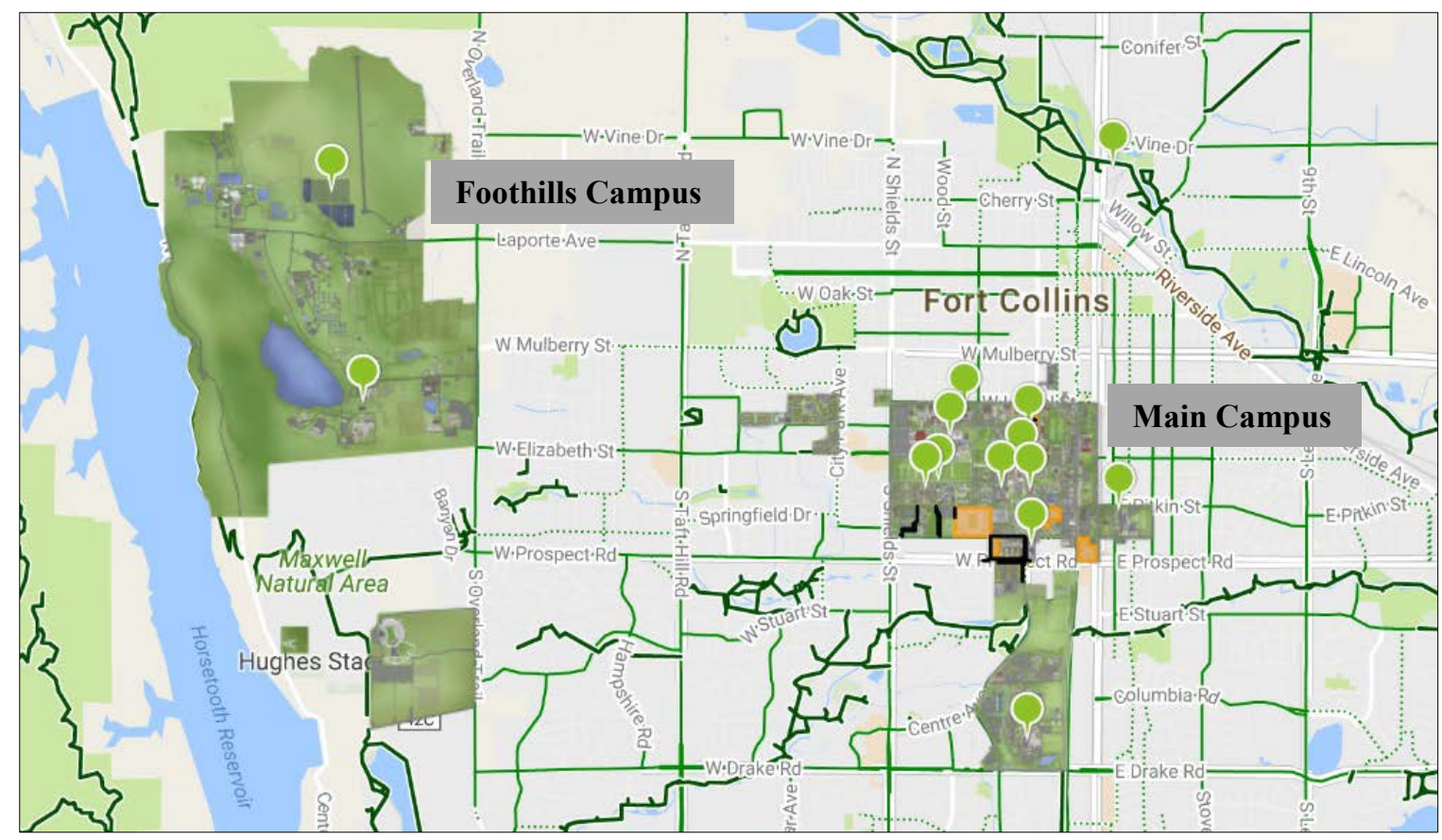

Figure 2. Map of solar installations at CSU ${ }^{18}$

$=$ Solar PV installations

As a multi-campus university, CSU has sufficient, suitable land and rooftop space on which to site a variety of solar energy projects. Bringing the projects to fruition, though, required a high degree of coordination and stakeholder involvement, both on campus and within the broader community. The City of Fort Collins and Fort Collins Utilities, Larimer County, and Xcel Energy were all involved at various stages as CSU developed its solar program. Internally, the Facilities Management team, the campus administration (President's Cabinet), the Office of General Council, and the CSU Board of Governors were all involved in key decisions. Student and staff engagement was also paramount; green initiatives, including on-site renewable energy generation, have emerged as a priority for current and prospective students. Responding to this demand is one of the driving factors in promoting campus solar and the institution's other energy and environment initiatives.

CSU's short- ( $0-7$ years), medium- (7-20 years), and long- (20+ years) term solar energy strategies assume that solar PV costs will continue declining. In the medium term, the school is pursuing solar PPA and lease mechanisms that do not immediately generate RECs for the university. However, in the long term, CSU will favor retaining ownership of the systems and associated environmental attributes over PPA relationships. Table 2 below provides a breakdown of CSU's solar energy goals by timeframe. In the meantime, CSU has also made one-time

\footnotetext{
${ }^{18} \mathrm{CSU}$ maps, maps.colostate.edu/.
} 
purchases of RECs to offset campus electric energy use and also anticipates developing wind energy as part of its overall renewable energy strategy. ${ }^{19}$

Table 2. Solar Electricity in CSU's Climate Action Plan ${ }^{20}$

\begin{tabular}{lllll}
\hline Timeframe & Solar Strategy & $\begin{array}{l}\text { Percent of Net } \\
\text { FY10 Emissions }\end{array}$ & $\begin{array}{l}\text { Annual Cost } \\
\text { Savings }\end{array}$ & $\begin{array}{l}\text { Annual Return on } \\
\text { Investment }\end{array}$ \\
\hline $\begin{array}{l}\text { Short: } \mathbf{0 - 7} \\
\text { years }\end{array}$ & $\begin{array}{l}\text { On-campus solar PV } \\
\text { systems installed on } \\
\text { buildings }\end{array}$ & $0.1 \%$ & $\$ 23,000$ & Not Applicable \\
$\begin{array}{l}\text { Medium: } \\
\begin{array}{l}\text { 7-20 } \\
\text { years }\end{array}\end{array}$ & $\begin{array}{l}\text { Larger ground-mounted } \\
\text { solar PV systems }\end{array}$ & $1.0 \%$ & $\$ 247,000$ & $13 \%$ \\
$\begin{array}{l}\text { Long: } 20+ \\
\text { years }\end{array}$ & Solar purchasing & $4.0 \%$ & & $7 \%$ \\
\hline
\end{tabular}

The strategies outlined in Table 2 represent both solar power systems that have already been installed at CSU and potential future additions. CSU-owned systems for which the university retained all environmental attributes constitute the short term strategy. The 5.3 MW installation at Christman Field falls under the medium-term plan because the environmental attributes currently owned by the utility, Xcel Energy, will revert to CSU when the university assumes ownership of the facility in 2030. Similarly, the environmental attributes for the $1.2 \mathrm{MW}$ of rooftop solar PV systems located on CSU's campus are currently owned by the local municipal utility, Fort Collins Utilities, but CSU anticipates purchasing both the systems and the associated RECs in 2035, contributing to the long-term emissions reductions projection. In the medium- and long-term scenarios, the existing PV systems do not directly contribute to either CSU's renewable electricity generation goals or its GHG emissions reduction strategies. ${ }^{21}$

\footnotetext{
19 "The College Sustainability Report Card: Colorado State University," Sustainable Endowments Institute, 2011. http://www.greenreportcard.org/report-card-2011/schools/colorado-state-university/surveys/campussurvey.html\#climate; CSU, Climate Action Plan.

${ }^{20}$ Adapted from CSU, Climate Action Plan.

${ }^{21}$ CSU, Climate Action Plan.
} 


\section{Deciding to Deploy Solar Photovoltaics}

Apart from sustainability goals, a number of factors facilitated CSU's entry into the solar PV market, including state grant funding; a desire on behalf of the institution to pursue visible, onsite renewable energy generation; and the opportunity to use available university-owned land. CSU's current portfolio of campus solar installations includes a variety of rooftop and groundmounted systems. Each project represents a unique set of decisions, considerations, and project development pathways.

The initial decision to pursue PV deployment at CSU emerged from a combination of long-term sustainability goals, financial considerations, and a desire to market the school as a "green" university. When CSU's first $18.9 \mathrm{~kW}$ installation came online in the summer of 2009, it was the largest system in the city of Fort Collins. About two-thirds of the installation cost for that first project was covered by a Colorado Energy Office (Governor's Energy Office at the time) conservation grant. ${ }^{22} \mathrm{CSU}$ had already been considering a move towards renewable energycampus administrators wanted an on-site solar installation - and the Colorado Energy Office grant created an opportunity to secure a high-visibility project with a relatively small capital investment from the university.

Visibility was a key driver in deciding where to site the initial solar PV array. Located on the Engineering Building on CSU's main campus, the system is designed to be visible from the plaza surrounding the student center, making it a recognizable feature to the many students who pass through the high-traffic area every day. The system is tilted at a 40 degree angle (from the horizon) to enhance system optimization, accommodate and screen existing HVAC equipment on the roof, and make it more noticeable (see Figure 3).

${ }^{22}$ Colorado State University, "Governor's Energy Office Helps Colorado State University with Project to Install Solar Panels on Engineering Building," news release, June 18, 2009, http://www.news.colostate.edu/Release/Print/4187. 


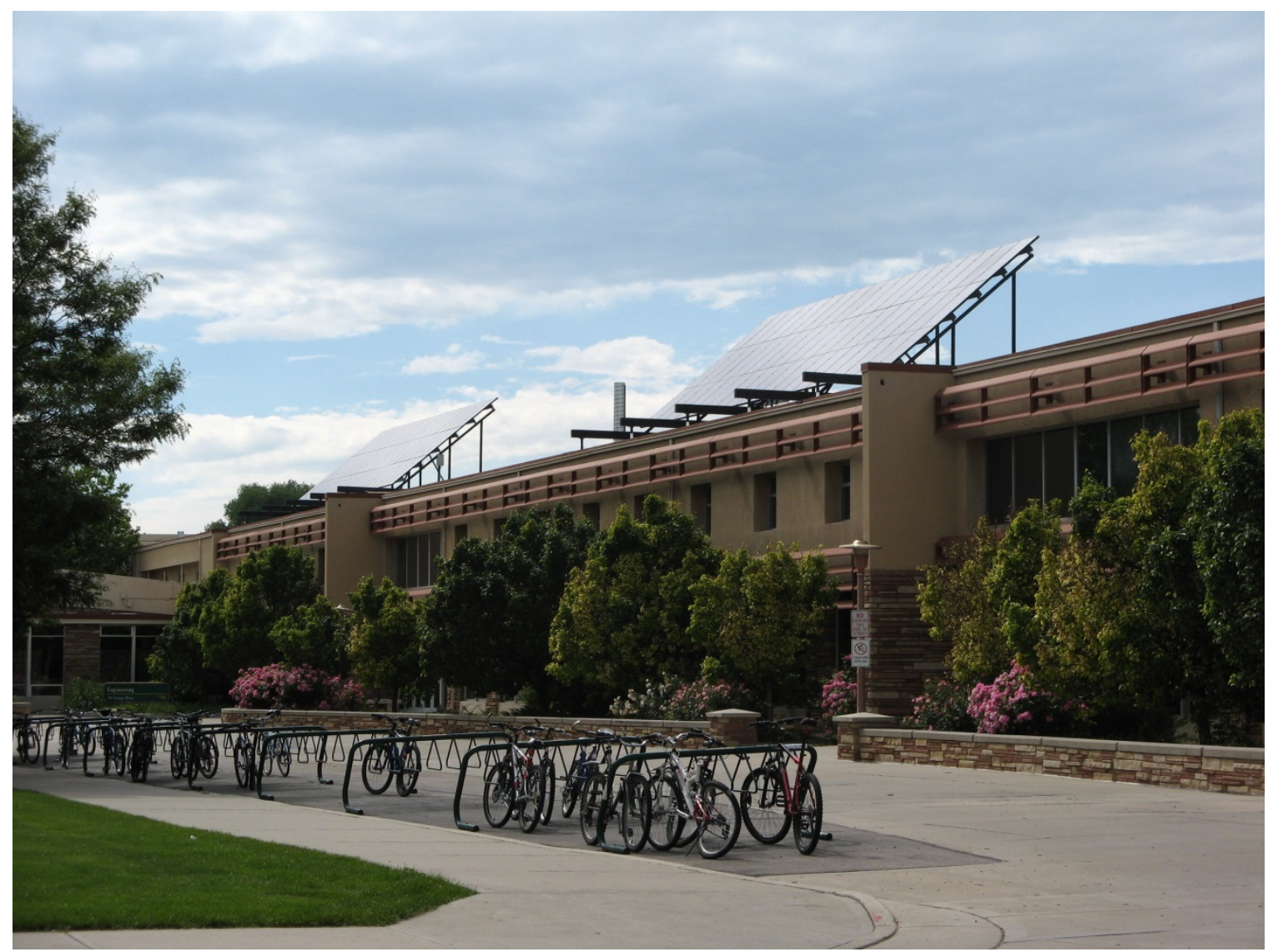

Figure 3. Rooftop PV system on the Engineering Building at CSU's main campus in Fort Collins

Photo credit: CSU

CSU's main campus is master-metered, meaning that any energy produced by solar energy systems installed on campus subtracts from the overall campus electricity load. While the initial $18.9 \mathrm{~kW}$ PV system barely registered on the broader 17-18 MW campus load, the City of Fort Collins required CSU to meet all interconnection standards. ${ }^{23} \mathrm{CSU}$ owns the $18.9 \mathrm{~kW}$ PV system outright and retains all environmental attributes (i.e., RECs) associated with the project. With this first system, CSU opted to forgo a small rebate incentive from the City of Fort Collins, which would have transferred REC ownership to the city. Capped at $10 \mathrm{~kW}$ of capacity, the rebate would have applied to about half of CSU's first solar PV installation, but Fort Collins would have assumed all of the RECs associated with the project. Transfer of REC ownership would preclude the university from claiming any environmental attributes of the system towards their climate goals, and would not contribute to marketing the university as a "green" school.

Though the $18.9 \mathrm{~kW}$ PV system was technically CSU's first, the institution had been in discussions for a much larger installation at its Foothills Campus for almost three years leading up to that point. In response to requirements of the new Colorado RPS established in November 2004, Xcel Energy (Xcel), the state's largest investor owned utility (IOU), launched a request for bids to secure incentives for midscale market solar installations. CSU partnered with MMA

\footnotetext{
${ }^{23}$ Interconnection standards regulate renewable energy systems and their connection to a larger grid system, mostly from a safety perspective.
} 
Renewable Ventures on its first bid for Xcel incentives, but that proposal - a joint bid with the University of Colorado (CU) — was rejected by the utility. While CSU was proposing a larger ground-mounted system, the CU portion of the bid included a series of rooftop installations with a higher overall capital cost requirement. Recognizing that the price point for the CSU groundmounted system would be more competitive, CSU put together an independent bid for a $2 \mathrm{MW}$ ground-mounted system about a year later, this time gaining approval from Xcel. Construction of the initial $2 \mathrm{MW}$ PV system at Christman Field (later expanded to $5.3 \mathrm{MW}$ ) began in the fall of 2008 and was completed in the spring of 2009.

The 5.3 MW Christman Field project had several selling points: it was sited on underutilized university-owned land, it would guarantee the price of one-third of the Foothills Campus' electricity purchases for 20 years, and it served as a marketing tool to entice potential students. The project was financed through a solar PPA, under which the university purchases electricity produced by the system for a fixed rate over a 20 -year term. Zero upfront capital costs and hedging against potential future utility rate increases were among the most persuasive arguments in securing stakeholder buy-in for the project. While CSU cannot currently claim the environmental attributes of solar energy generated by the Chistman Field project, the system provides important economic and educational benefits and the university plans to fully own both the energy and RECs after the initial 20-year PPA term. As one CSU representative noted, the university was able to take advantage of a narrow window in the solar market during which the price of panels were dropping and incentives were still high. This combination of factors paved the way for a midscale market sized solar PV installation at CSU.

The two examples mentioned in this section set the stage for further PV deployment at CSU and highlight some of the overarching considerations involved in the early decisions about whether to pursue on-campus solar development. The various PV installations at CSU have all been configured slightly differently, reflecting the quickly evolving solar market landscape. Subsequent sections of this case study discuss the formal development and approval processes in more detail. 


\section{Christman Field Project Development}

The largest of CSU's solar PV installations was developed in two phases between 2009 and 2010. CSU was able to employ underutilized land at the university's Foothills Campus that it already owned to develop the system, a critical factor in making the project feasible. CSU was also able to tap into in-house expertise to facilitate certain aspects of project permitting and development. Table 3 summarizes the system and its various phases.

Table 3. Christman Field Solar Development Snapshot

\begin{tabular}{lll}
\hline & Christman Field Phase 1 & Christman Field Phase 2 \\
\hline Year installed & 2009 & 2010 \\
System type & $\begin{array}{l}\text { Ground-mount, single-axis } \\
\text { tracking }\end{array}$ & Ground-mounted, fixed-tilt \\
\hline Capacity & $2 \mathrm{MW}$ & $3.3 \mathrm{MW}$ \\
\hline Annual electricity production & $3,500,000 \mathrm{kWh}$ & $5,000,000 \mathrm{kWh}$ \\
\hline Number of inverters & 4 & 6 \\
\hline Incentives & Feed-in tariff & Feed-in tariff \\
\hline REC ownership & Xcel Energy & Xcel Energy \\
\hline Developer & MMA Renewable Ventures, & Fotowatio Renewable Ventures \\
\hline Current owner & Ventures & \\
\hline Installer & SunEdison & SunEdison \\
\hline
\end{tabular}

The following subsections outline the planning, approval, and financing processes for the Christman Field PV system.

\subsection{Planning}

In planning the 5.3 MW PV array at Christman field, the specific project configuration-how it was financed, where it was located, who owned the system - dictated who needed to be involved in the decision-making processes. CSU's Facilities Management team addressed the physical land-use aspects of project development; campus administration had to be convinced of the project benefits and approve development and site lease; the General Counsel's office was involved in PPA development and negotiations.

CSU evaluated several locations to determine where to site the ground-mounted PV array. The university was less concerned about visibility for the ground-mounted system compared with the university's original $18.9 \mathrm{~kW}$ rooftop PV installation; initial siting considerations prioritized areas that would not consume land where future buildings could otherwise be sited. At the same time, the site had to be suitable for construction and interconnection with the local distribution system. Because the project was being developed with incentives from Xcel, the site had to be located within the utility's service territory. This ruled out any sites on CSU's main campus, which falls within Fort Collins Utilities' service territory. Christman Field, a retired air strip that 
was functioning as an unused horse pasture, emerged as the most viable site. Figure 4 shows the air strip with the installed ground mounted PV system.

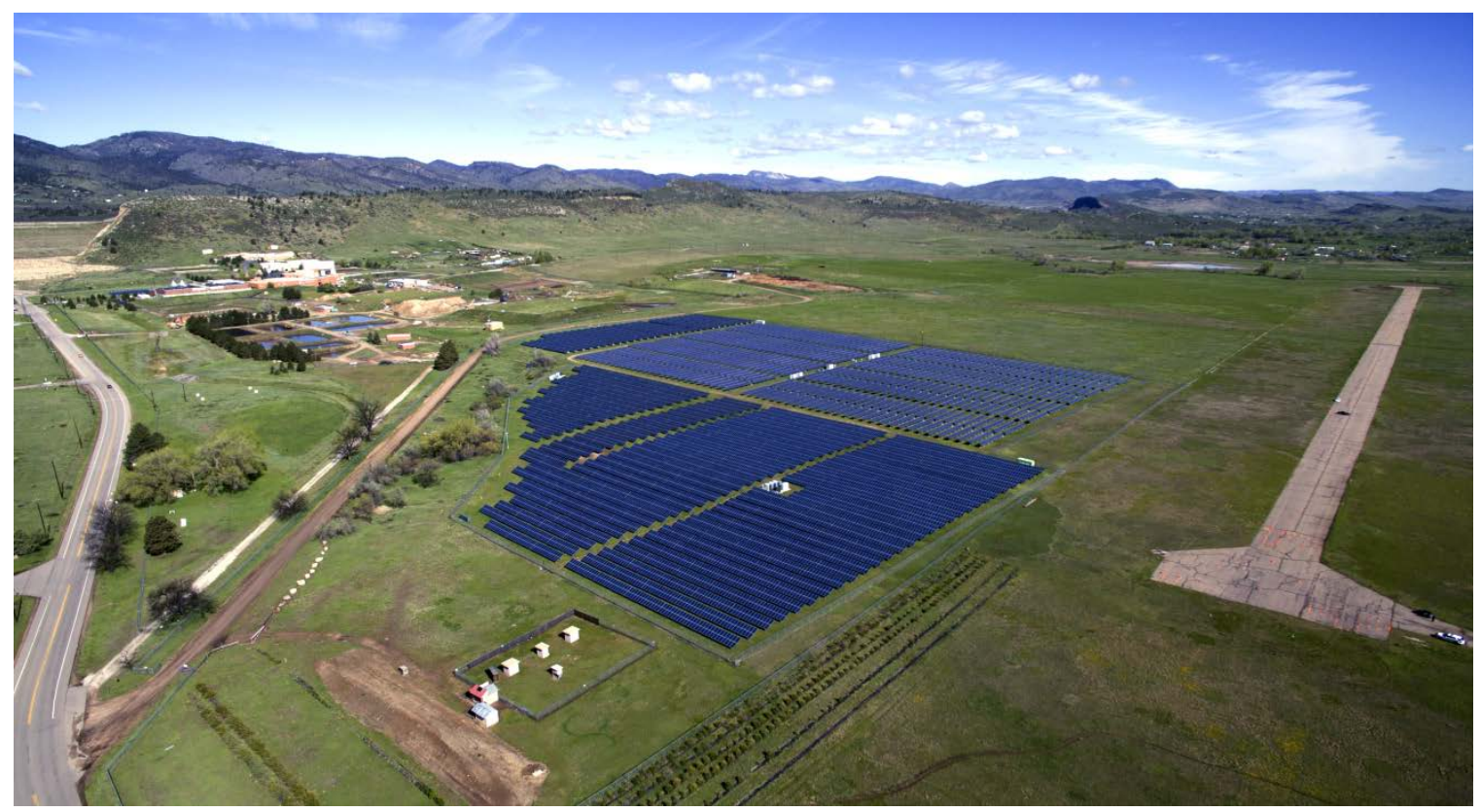

Figure 4. 5.3 MW solar PV array at Christman Field on CSU's Foothills Campus

Photo credit: CSU

\subsection{Getting Approval}

During the bidding process with Xcel, university approval came from the Facilities Director. No additional approvals were needed at that point because there were no financial commitments associated with the bid. ${ }^{24}$ After Xcel awarded CSU the solar development incentives, the Facilities Management team prepared and presented a financial package to university administrators, including the President's Cabinet, for final approval to bring the project to fruition.

The financial tool that ultimately enabled the Christman Field project was a plan to purchase the PV-generated electricity via a PPA. As an institution, CSU was already interested in pursuing solar as part of its broader sustainability goals, and the hedging opportunity against electricity rate increases was a major selling point to the campus administration. At the time of approval, the PPA price was competitive with existing electricity rates and the university was projecting a $5-10 \%$ escalation in traditional electric rates over the same period (20 years).

The permitting process for the 5.3 MW PV system at Christman Field involved a number of city, county, and university actors, policies, and regulations. CSU was able to contract internally with university staff for all permitting requirements, a unique feature of the university system. For example, the university worked with a CSU botanist to survey the site for a specific endangered plant, which was not found in the area. All of the required geographic information systems (GIS) work and environmental reviews were conducted by in-house experts. CSU did, however,

\footnotetext{
${ }^{24} \mathrm{Xcel}$ has since changed this process due to an overload of bids from entities that were ultimately unable to move forward with proposed projects.
} 
consult with the U.S. Fish and Wildlife Service and the Army Corps of Engineers to assess water drainage issues in the site design process.

Larimer County, where the Foothills Campus is located, requires a Location \& Extent (L\&E) review to ensure that all proposed public uses, structures, or utilities conform to the county's master plan. Larimer County initially granted CSU a waiver on the L\&E requirement for Phase 1 of the Christman Field project, ruling that the $2 \mathrm{MW}$ solar facility did not constitute a structure. However, after Phase 1 was complete, the county introduced a new permitting process, called 1041 Permits, which requires review and approval for new construction deemed "matters of the state." ${ }^{25}$ Due to this regulatory addition, CSU had to research and evaluate the project site and adjacent lands for issues related to rare and endangered plants and animals, wildlife hazards, steep slopes, critical wildlife areas, wetlands, Federal Emergency Management Agencydesignated flood zones, geologic hazards, and cultural resources.

The county 1041 process, which is still in place as of the end of 2016, did not significantly impact CSU's project development timeframe. Surveying and permitting for the Christman Field site was completed in parallel with the design process from February to July 2009, with construction beginning in August 2009. In addition to the 1041 permit, other required permits included road crossing approval for power lines, a storm water management plan and permit for the project construction phase, and structural and electrical code reviews. CSU's status as a state institution created unique jurisdictional boundaries throughout the permitting process. In this case, CSU has authority over power, water, and building inspections and completed all associated permitting requirements in-house.

\subsection{Financing}

CSU partnered with MMA Renewable Ventures (MMA) — one of two qualified bidders that responded to a request for information solicitation for the project - to develop and own the Christman Field solar PV facility. After Phase 1 was complete, Fotowatio Renewable Ventures (FRV), a Spanish solar developer, purchased MMA, assuming responsibility over the project. About a year after Phase 2 was complete, FRV sold all of its U.S. solar operations to SunEdison, the current project owner. SunEdison, however, was never involved in the project development or construction phases.

The PPA between CSU and the project developer included incentives from Xcel Energy. CSU will have the opportunity to buy-out the contract and assume ownership of the system and associated RECs at several junctures during the 20-year contract lifetime. The first eligible buyout period opened in 2016, but CSU opted to remain in the PPA contract. Additional details about the PPA rates, terms, and incentives are proprietary.

CSU essentially donated the project site - the developer pays a nominal amount to lease the land - but the PPA otherwise allowed CSU to avoid upfront capital investment. While CSU signed a non-disclosure agreement and cannot release the PPA price, university officials have commented that the cost of electricity under the PPA was competitive with the electricity rate at the time. While the cost of electricity has not escalated as much as originally anticipated,

\footnotetext{
${ }^{25}$ Larimer County defines "matters of the state" as large projects developed by non-county entities and that involve public utilities.
} 
rendering the hedging opportunity less substantial than initially projected, during the 20 year contract term the university will realize significant cost savings and the project remains financially attractive to the university.

\subsection{Design, Construction, and Interconnection}

Following project approval, Phase 1 of the Christman Field installation took about four months to design and construct: one month for design and three months for construction. One design consideration that is unique to Phase 1 is that Christman Field has a design wind speed of 110 miles per hour, but tilted tracking is only rated for gusts up to $90 \mathrm{mph}$, so the system had to be designed for single-axis tracking with no tilt. The university remained closely involved in the design and construction phase due to a number of site complications, including county development procedures and storm water and water rights issues. At one point, CSU considered expanding the panel locations across a drainage area, but abandoned the idea after learning that doing so would require wetland delineation. Western boundaries of the site are, therefore, constrained by a drainage area.

The PV system was originally constrained under Colorado's RPS implementation rules, which capped incentives at $2 \mathrm{MW}$. About halfway through the construction of Phase 1 of the Christman Field system, the Colorado PUC removed the $2 \mathrm{MW}$ capacity limit on solar PV installations. At that point, the project developer approached CSU to suggest additional development. This was a period when incentives were high and the price of panels was dropping, and CSU quickly negotiated and approved Phase 2 of the project. Because the university had allocated a 30 -acre site for solar development but only 15 acres were needed for a 2 MW tracking system, Phase 2 amounted to filling out the remaining 15 acre area with an additional 3.3 MW array. Due to a combination of terrain and geography, the second phase had to be non-tracking (fixed-tilt). Construction of Phase 2 was completed in December 2010.

For both phases, an interconnection agreement was negotiated between Xcel and the solar developer. Interconnection refers to the process of physically connecting distributed (or on-site) energy facilities to the utility grid.

Finally, the RECs associated with the Christman Field project helped Xcel to meet its renewable energy generation requirements under Colorado's RPS. Colorado's RPS at the time specified that IOUs (like Xcel) had to secure $10 \%$ of capacity from renewable sources, of which $4 \%$ had to be solar and, of that, half had to be customer-sited. This yielded a small, but favorable, window for this type of customer-sited arrangement. Now fully operational, the 5.3 MW system produces 8.5 MWh annually_ just over a third of the Foothills Campus' 25 MWh annual consumption. 


\section{Campus Building PV Project Development}

In addition to the Christman Field array, 13 CSU buildings are currently outfitted with solar PV installations: 12 rooftop PV systems and one ground-mount system. Of those 13 installations, just over half are university-owned, several of which were developed as part of new building construction. The university-owned systems enable the school to claim the associated RECs, which increases the system value above the electric energy offset by the systems. The remaining PV systems were developed under roof-lease agreements with Fort Collins Utilities. Table 4 below summarizes the projects by location, size, installation year, owner, and financing mechanism.

Table 4. Summary of CSU Solar PV Systems

\begin{tabular}{|c|c|c|c|c|c|}
\hline Project & $\begin{array}{l}\text { System } \\
\text { Size (kW) }\end{array}$ & $\begin{array}{l}\text { Year } \\
\text { Installed }\end{array}$ & $\begin{array}{l}\text { System } \\
\text { Owner }\end{array}$ & $\begin{array}{l}\text { REC } \\
\text { Owner }\end{array}$ & Financing \\
\hline $\begin{array}{l}\text { Engineering } \\
\text { Building }\end{array}$ & 18.9 & 2009 & CSU & CSU & $\begin{array}{l}\text { Colorado Energy Office } \\
\text { grant, CSU }\end{array}$ \\
\hline $\begin{array}{l}\text { Lake Street } \\
\text { Parking Garage }\end{array}$ & 132.5 & 2010 & CSU & CSU & $\begin{array}{l}\text { CSU, new building } \\
\text { project budget }\end{array}$ \\
\hline Academic Village & 12.6 & 2009 & CSU & CSU & $\begin{array}{l}\text { CSU, new building } \\
\text { project budget }\end{array}$ \\
\hline $\begin{array}{l}\text { Behavioral } \\
\text { Science Building }\end{array}$ & 15.8 & 2010 & CSU & CSU & $\begin{array}{l}\text { CSU, new building } \\
\text { project budget }\end{array}$ \\
\hline $\begin{array}{l}\text { Research } \\
\text { Innovation } \\
\text { Center* }\end{array}$ & 54.0 & 2010 & CSU & CSU & $\begin{array}{l}\text { CSU, new building } \\
\text { project budget }\end{array}$ \\
\hline $\begin{array}{l}\text { The Cube at } \\
\text { Morgan Library }\end{array}$ & 4.3 & 2012 & CSU & CSU & $\begin{array}{l}\text { CSU, new building } \\
\text { project budget }\end{array}$ \\
\hline Powerhouse & 21.6 & 2013 & CSU & CSU & $\begin{array}{l}\text { CSU, new building } \\
\text { project budget }\end{array}$ \\
\hline Braiden Hall & 99.9 & 2014 & $\begin{array}{l}\text { Atmosphere } \\
\text { Conservancy }\end{array}$ & $\begin{array}{l}\text { Fort Collins } \\
\text { Utilities }\end{array}$ & $\begin{array}{l}\text { Third party developer, } \\
\text { roof lease agreement }\end{array}$ \\
\hline Parmelee Hall & 139.1 & 2015 & $\begin{array}{l}\text { Atmosphere } \\
\text { Conservancy }\end{array}$ & $\begin{array}{l}\text { Fort Collins } \\
\text { Utilities }\end{array}$ & $\begin{array}{l}\text { Third party developer, } \\
\text { roof lease agreement }\end{array}$ \\
\hline Edwards Hall & 91.8 & 2015 & $\begin{array}{l}\text { Atmosphere } \\
\text { Conservancy }\end{array}$ & $\begin{array}{l}\text { Fort Collins } \\
\text { Utilities }\end{array}$ & $\begin{array}{l}\text { Third party developer, } \\
\text { roof lease agreement }\end{array}$ \\
\hline $\begin{array}{l}\text { University Center } \\
\text { for the Arts }\end{array}$ & 98.5 & 2015 & $\begin{array}{l}\text { Atmosphere } \\
\text { Conservancy }\end{array}$ & $\begin{array}{l}\text { Fort Collins } \\
\text { Utilities }\end{array}$ & $\begin{array}{l}\text { Third party developer, } \\
\text { roof lease agreement }\end{array}$ \\
\hline $\begin{array}{l}\text { Veterinary } \\
\text { Teaching Hospital }\end{array}$ & 220.2 & 2015 & $\begin{array}{l}\text { Atmosphere } \\
\text { Conservancy }\end{array}$ & $\begin{array}{l}\text { Fort Collins } \\
\text { Utilities }\end{array}$ & $\begin{array}{l}\text { Third party developer, } \\
\text { roof lease agreement }\end{array}$ \\
\hline $\begin{array}{l}\text { Student } \\
\text { Recreation } \\
\text { Center }\end{array}$ & 544.7 & 2015 & $\begin{array}{l}\text { Atmosphere } \\
\text { Conservancy }\end{array}$ & $\begin{array}{l}\text { Fort Collins } \\
\text { Utilities }\end{array}$ & $\begin{array}{l}\text { Third party developer, } \\
\text { roof lease agreement }\end{array}$ \\
\hline
\end{tabular}




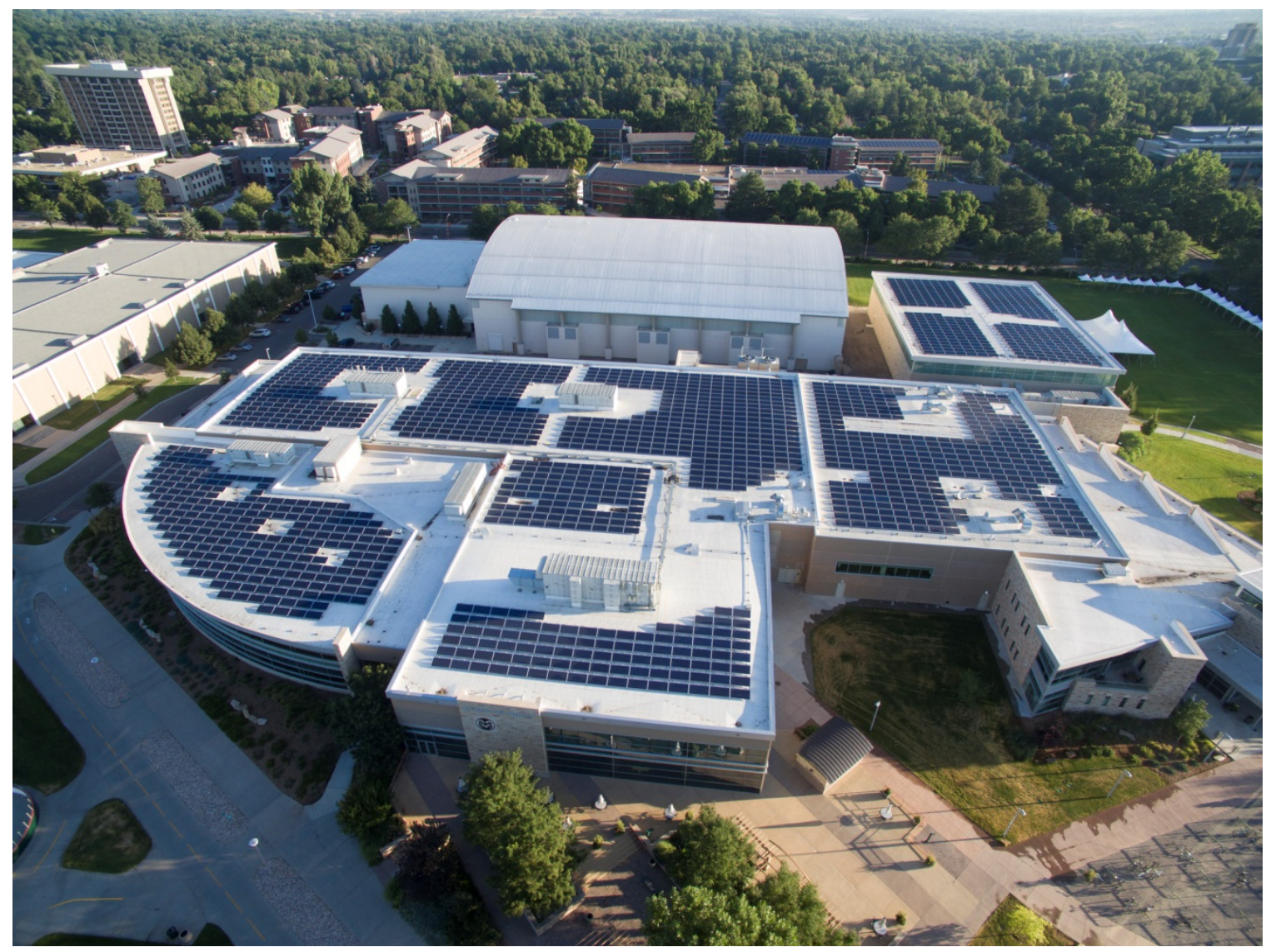

Figure 5. Rooftop PV on CSU's Student Recreation Center

Photo credit: CSU

\subsection{CSU-Owned Systems}

CSU directly owns and retains all RECs associated with the PV systems installed on its main campus prior to 2015. With the exception of the initial grant-funded $18.9 \mathrm{~kW}$ system on the Engineering Building, all other university-owned rooftop PV systems were developed and paid for through new building construction to obtain Leadership in Energy and Environmental Design (LEED)-certified buildings. ${ }^{26}$ Overall, the $260 \mathrm{~kW}$ of CSU-owned systems amount to a small portion of the campus PV capacity-less than $20 \%$ of the PV installed on or at buildings and less than $4 \%$ of the total institution-wide solar.

The PV systems were included in the cost of construction through a mechanism known as budget "add-alternates" - budget line items that move forward if funding is still available after completing higher ranked construction priorities. Budget add-alternates essentially constitute a wish list of desirable building features. In CSU's case, because several new building construction budgets were developed around 2007 and the economy suffered a major hit in 2009, the actual construction costs for those buildings came in significantly under budget. This provided flexibility in the budgets and facilitated the installation of rooftop PV systems. Conversely, CSU

\footnotetext{
${ }^{26}$ Additional points are given to buildings with on-site renewable energy sources under the U.S. Green Building Council's Leadership in Energy and Environmental Design (LEED) green building certification program.
} 
is currently experiencing the opposite problem: construction costs are exceeding the estimated budget figures made several years ago.

CSU's largest owned system is a $133 \mathrm{~kW}$ array on the rooftop of a LEED Gold certified parking garage - a designation that no longer exists because LEED stopped certifying parking structures. With money still available in the construction budget at the end of the building construction, the developer issued a reverse-bid for solar PV (i.e., soliciting developers to bid on how much solar PV could be installed for a given dollar amount) through the electrical contractor. Funding for the PV system ultimately came out of remaining budgets for both the parking structure and for another new building that desired the addition of renewable energy but did not have adequate roof space to support solar.

\subsection{Roof-Lease PV Systems with Fort Collins Utilities}

CSU added 1.2 MW of rooftop PV in 2015 under a series of roof-lease agreements incentivized through Fort Collins Utilities' Solar Power Purchase Program (SP3). Under this arrangement, electricity from the PV systems goes directly into Fort Collins Utilities' electric grid. CSU does not purchase the power, nor does it claim any environmental attributes associated with the systems. A third-party entity owns and operates the systems and pays a roof lease to CSU; Fort Collins Utilities pays the solar developer for the power and the RECs. The only short-term benefit the university derives from this arrangement is the nominal income from the roof lease payments. The university cannot claim the power generated by these systems towards its climate or sustainability goals because the RECs are retained by Fort Collins Utilities. After 20 years, CSU has the option to buy out the systems, assuming ownership of both the electricity and RECs generated by the systems from the date of purchase, thereby contributing to the institution's long-term GHG emissions reductions strategy.

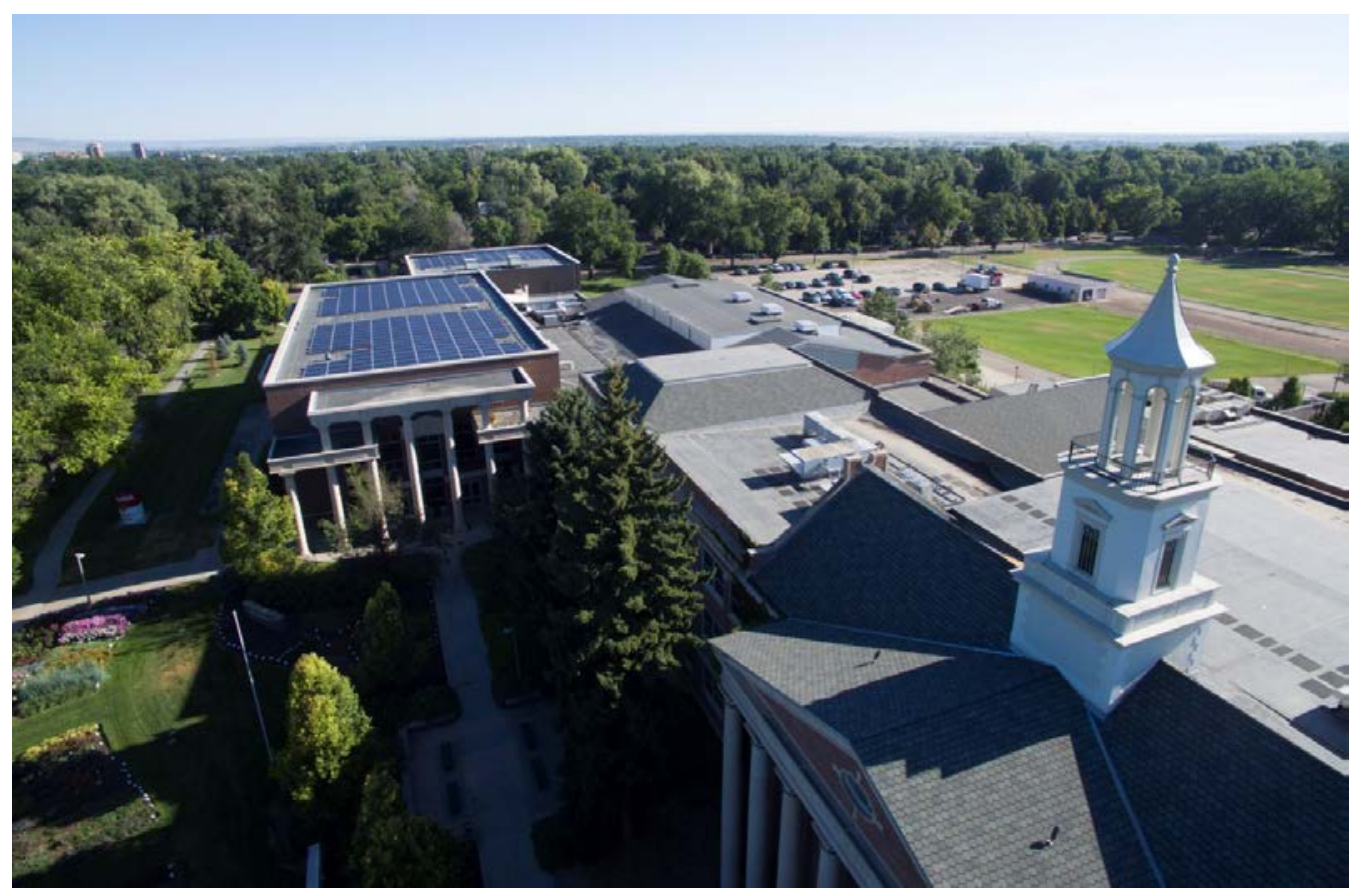

Figure 6. Rooftop PV on CSU's University Center for the Arts

Photo credit: CSU 


\section{Summary of Challenges and Approaches}

Since CSU's first solar PV installation came online, the university has accumulated many lessons-learned. The sections below highlight some of the key financial, technical, and regulatory challenges the institution faced in developing its overall solar PV portfolio.

\subsection{Financial and Regulatory}

- Lack of streamlined financing sources and procedures.

For each solar project, CSU had to be creative with financing options - in some cases using contract add-alternates, sometimes receiving state or local incentives, other times working through a PPA. While this did not become a barrier to any individual project, financing procedures can complicate an institution's PV deployment trajectory.

\section{- Shifting utility financial incentives.}

Navigating various utility incentives structures can be challenging. In CSU's case, this meant revising projects and bids several times before they received incentives and were able to move forward.

- Mismatch between utility financial incentives and optimal design configuration.

A related issue that CSU encountered is that the incentives available did not necessarily align with optimal system configuration. Several of the campus systems are sized to take advantage of the incentives but do not maximize available roof capacity.

- Contributing to climate change mitigation and sustainability goals.

With each decision to install a solar PV system, a university must balance the financial trade-off between retaining the associated RECs and buying RECs in the open marketplace in order to meet the institution's climate change, sustainability, and/or renewable energy goals. Because CSU does not retain most of the RECs from its various solar PV installations, the university cannot claim many positive environmental attributes in the near-term. However, the university does plan to eventually take ownership of the RECs from many on-campus solar PV installations, which will contribute to the institution's long-term climate and sustainability goals.

\subsection{Technical}

- Roof availability and condition.

CSU noted that in times of tight funding, roofs often do not get replaced promptly. Because roofs must be in good condition to support rooftop solar PV installations, many older buildings may be disqualified as potential sites for future PV development, decreasing the amount of suitable space for PV development.

- Land availability.

CSU had significant available land in Christman Field for its 30 acre, $5.3 \mathrm{MW}$ groundmounted system. However, limited additional available land may constrain future solar development. 


\subsection{Other Challenges}

\section{- Institutional learning curve.}

Although CSU did not encounter any restrictive regulatory barriers, there was a significant learning curve in CSU's approach to on-campus solar development. Learning about the process took time. CSU benefited from having in-house resources (e.g., technical experts who could help with the site evaluation and permitting processes). For Phase 1 of the Christman Field project, for example, it took longer to negotiate contracts ( 5 months) than to actually build the project (3 months). Legal staff had to learn the various aspects of a PPA - a type of contract that CSU had not previously encountered. Campus administrators also had to be educated on lease terms, solar facility operations, and similar aspects of project development. By the time Phase 2 began, the contract negotiation process took only five days. 


\section{Conclusions}

Between 2009 and 2015, CSU evolved into one of the leading institutions for campus solar development in the United States. The dramatic expansion from an initial $18.9 \mathrm{~kW}$ PV system to over 6.7 MW is a strong indication of the potential for the campus solar market.

CSU constantly evaluates the solar PV landscape and tries to plan its next move. Relatively small rooftop arrays are likely as part of new buildings, which are designed to be renewable-ready, but $\mathrm{CSU}$ is also investigating large ground-mount systems because of the financial advantage of utility-scale installations. Solar PV is an important tool to help meet the university's long-term goal of carbon neutrality.

As highlighted throughout this case study, CSU's solar development trajectory was not always straightforward. CSU had to navigate a shifting external solar landscape, including changing state, county, and local policies, regulations, and incentives while developing internal institutional capacity to address solar development on campus. CSU benefited from having ample available, underutilized land on which to site a major solar facility, a feature not necessarily common to all universities. The institution was also able to draw on significant inhouse expertise for various aspects of project planning and permitting.

Every institution faces a unique set of challenges depending on the state and local contexts and campus-specific circumstances. CSU's experiences, along with examples from other universities, provide a case study for other institutions seeking to pursue solar PV deployment. Many of the issues CSU encountered, including the variable avenues for financing PV systems, project siting considerations, and internal decision-making processes, are common across institutions. CSU's path can thus help inform other universities' approaches to mid-market scale on-campus solar PV deployment. 


\section{Appendix. Additional NREL Resources}

Technical Assistance: Solar Screenings and Implementation Assistance for Universities

U.S. Department of Energy's National Renewable Energy Laboratory (NREL) offers no-cost technical assistance to universities seeking to go solar. For more information, visit http://www.nrel.gov/technical-assistance/universities.html.

\section{Informational Resources}

Bird, Lori, Pieter Gagnon, and Jenny Heeter. 2016. Expanding Midscale Solar: Examining the Economic Potential, Barriers, and Opportunities at Offices, Hotels, Warehouses, and Universities. NREL/TP-A620-65938. Golden, CO: National Renewable Energy Laboratory. http://www.nrel.gov/docs/fy16osti/65938.pdf.

Heeter, Jenny, and Eric O’Shaughnessy. 2016. “Using Power Purchase Agreements for Solar Deployment at Universities." Presented February 24.

http://www.nrel.gov/docs/fy16osti/66119.pdf.

National Renewable Energy Laboratory. 2016. "Using Power Purchase Agreements for Solar Deployment at Universities.” BR-6A20-65567. http://www.nrel.gov/docs/gen/fy16/65567.pdf. 